\title{
Corporate Governance, Firm Age, and Leverage: Empirical Evidence from China
}

\author{
Zulfiqar Ali Memon ${ }^{1^{*}} \quad$ Yan Chen $^{2}$ Ayaz Ali Samo ${ }^{3}$ \\ 1.School of Accounting, Dongbei University of Finance and Economics, Dalian, Liaoning, China \\ 2.China Internal Control Research Centre and School of Accounting, Dongbei University of Finance and \\ Economics, Dalian, Liaoning, China \\ 3.School of Business Administration, Shah Abdul Latif University, Khairpur, Pakistan
}

\begin{abstract}
This study aims to analyze the influence of corporate governance on firm leverage. It also investigates the moderating effect of firm age on the association between corporate governance and leverage. Using a sample of Chinese listed firms, it addresses several issues that have been identified in the prior literature regarding capital structure. This study provides novel findings which reveal that CEO duality and board commissions have a statistically significant role in determining the leverage levels for NSOEs, however, the positive effect of board commissions established on leverage decreases as the firm ages. Board size, board independence and supervisory boards influence the leverage levels for SOEs, however, the negative effects of board independence and supervisory boards on leverage reduce as the firm grows older.
\end{abstract}

Keywords: Corporate governance, leverage, firm age, Chinese listed firms

DOI: $10.7176 / \mathrm{RJFA} / 10-2-03$

\section{Introduction}

The fundamental objective of a firm is the maximization of the wealth of shareholders. Corporate governance and firm leverage play a major role in maximizing the wealth of shareholders. Strong corporate governance leads to the enhancement of firm value (Black, 2000; Gompers et al., 2003; Rouf, 2014), whereas high leverage leads to a decline in the firm value due to increased risk of bankruptcy (Obradovich \& Gill, 2012). It is therefore necessary for a firm to establish a strong governance and an optimal capital structure.

Corporate Governance has been defined as the control systems and practices through which investors or lenders get assurance of receiving returns on the money they invested (Shleifer \& Vishny, 1997). A solid and well established corporate governance system is important for the rapid advancement of an economy. The countries with strong corporate governance systems have been able to rapidly expand their corporate sector by bringing more capital into their economies at lower costs, thereby increasing the value of the firm and maximizing the wealth of the shareholders (Ahmed Sheikh \& Wang, 2012). Integration of China's economy into the global economy along with the speedy development of capital markets enabling higher investment from different countries have caught the attention of researchers to investigate the governance structure of the firms in China (Y. S. Huang \& Wang, 2015; Liu \& Fong, 2010; Wei, 2007; Xu \& Wang, 1997).

Several previous studies report that various attributes of a firm change as it grows older, and those changed attributes thus affect the behavior of the firms. According to Hovakimian et al. (2001) and Sundaresan et al. (2015), when a firm grows older, it has less growth options and more assets-in-place which give the ground for higher leverage. Some studies also report that after going public, and especially after IPO, the suitability of governance attributes for firms at different levels of age is different (Filatotchev et al., 2006). According to Johnson et al. (2016), the advantages of takeover defenses decrease over the firm life cycle as the firm ages which leads to a decline in firm's value (particularly for the firms having more rigid defenses), indicating that the influence of these attributes might be different on leverage related decisions as the firm grows older.

In the light of above arguments, we first examine empirically if corporate governance plays any role in determining the leverage structure of Chinese firms, and whether this relationship is different for firms at different age levels or not. To do so, we address the concerns about capital structure measures as identified by Welch (2007). For instance, previous studies use flawed debt-to-asset ratio to measure the leverage, however, debt-to equity is more appropriate. Besides, prior studies use linear regression models to determine the association between corporate governance and firm leverage, the estimation results of which are not reliable. When the dependent variable is a fractional variable, such as leverage, whose value is bounded between 0 and 1 , the conditional expectation function for such bounded variable is non-linear. We therefore follow the Papke and Wooldridge (1996) and apply GLM (Generalized Linear Model) with logit link function to analyze how corporate governance affects leverage structure and the moderating effect of firm age on this relationship.

We divide our entire sample into NSOEs (Non-State Owned Enterprises) and SOEs (State Owned Enterprises) and find that board independence and supervisory boards for SOEs are negatively associated with firm leverage, whereas board size is positively associated to leverage. CEO duality and board commissions established for SOEs do not show statistically significant relationship with leverage. For NSOEs, we find that 
CEO duality has a negative association, while board commissions established have a positive association with firm leverage.

We find that firm age negatively moderates the positive association between number of commissions established and leverage for NSOEs, may be due to the preference of NSOEs to use more equity than debt as they age. On the other hand, firm age positively moderates the negative effects of board independence and supervisory board on leverage for SOEs, may be due to the lower costs of debt for SOEs as they grow older. Our findings are robust to alternative measures of leverage and firm age, and we also test that our findings are not influenced by endogeneity issues.

Our study contributes to the literature in various ways. First, this study provides some novel findings about the effect of firm age on the relationship between corporate governance and leverage in the context of Chinese listed firms which have a unique and distinctive institutional and governance structures than those of developed countries. The closest research in this regard is by Kieschnick and Moussawi (2018), but it is based on the listed firm in United States. Second, this study not only provides that firm age moderates the relationship between governance measure and leverage, but it also provides an in-depth analysis of how various levels of firm age affect the effect of governance on leverage. Finally, our study addresses the identified concerns about leverage measures which have been ignored in previous researches thereby making our findings more reliable.

The remainder of our paper is organized as follows. Section 2 presents our sample and methodology used for this study. Section 3 analyzes and discusses the results. Section 4 presents the robustness of our findings. Finally, Section 5 concludes our study.

\section{Sample Description, Measurement of Variables, and Research Design}

2.1 Sample

Our sample consists of all A-shares issuing non-financial companies listed on Shenzhen and Shanghai Stock Exchanges. We obtain all the required data for this study from CSMAR (China Stock Market and Accounting Research Database). For our analysis, we divide our sample into SOEs and NSOEs based on the company actual controller data available in CSMAR. Since this data is only available from 2003 onwards, therefore, we restrict the time period of entire sample from 2003 to 2017. We remove all those firms from our sample that have negative total assets, sales or equity. Our final dataset consists of 3,026 firms with 26,924 firm-year observations.

\subsection{Measures of Corporate Governance \\ 2.2.1 Board Size}

The size of the board plays a crucial role in firm's operating and financing decisions. We measure board size as the number of directors on the board. There is no agreement in the existing literature on the optimal board size. Jensen (1993) and Cheng (2008) claim that larger boards are less efficient and detrimental for firms, while Bacon and Brown (1973) and Oliver (2004) offer arguments in favour of large board size. The number of directors serving on the board, as stipulated by the Corporate Law in China, can be from five to nineteen.

\subsubsection{Board Independence}

We measure board independence as the number of independent directors i.e. non-executive or non-managerial directors on the board. The role of independent directors is very essential as they can monitor the activities of the board so as to verify the integrity of the board process, especially in the firms having concentrated ownership (Wu et al., 2001).

\subsubsection{Supervisory Board Size}

There is a two-tier board structure in Chinese firms, which comprises of Board of Directors and Board of Supervisors. We measure supervisory board size as the number of members serving on the Board of Supervisors. The main tasks of the supervisory board include reviewing the firm's financial affairs, supervising the infringements by the directors and executives while carrying out their duties, and demanding to remedy any action performed by the directors or executives which is not in the interest of the firm (Wei, 2007).

\subsubsection{CEO Duality}

CEO duality refers to the situation when CEO is also the chairperson of the board. Most of the Previous studies, for example, Daily and Dalton (1994) and Bai et al. (2004) argue that CEO duality in harmful for firms because it grants more power to the $\mathrm{CEO}$, thereby limiting the capability of the board to supervise and regulate the actions of the management. We measure CEO duality by a dummy variable which takes the value of 1 if the position of CEO and Chairperson are held by the same person and 0 otherwise.

\subsubsection{Board Commissions}

Board commissions are normally created in large firms under the authority of the board with the intention to augment the overall corporate governance mechanism (Liu \& Fong, 2010). We measure board commissions as the number of commissions formed by the board. The most common commissions found in the Chinese firms are: audit commissions, strategic commissions, nomination commissions, and remuneration and evaluation commissions. 


\subsection{Measures of Firm Age}

Firm age can be measured as the number of years from the incorporation of the firm to the current time. It can also be measured as the number of years since the firm got listed on stock exchange. For our analysis, we follow Kieschnick and Moussawi (2018) and use the listing date to measure firm age. Filatotchev et al. (2006) and Johnson et al. (2016) argue that the span of time that a company gets listed plays a crucial role in determining how it affects the governance in listed firms.

Nevertheless, a large number of prior studies use the time period since the incorporation of the firm as a measure of firm age. Therefore, we also use this measure in our robustness section.

\subsection{Measures of Leverage}

There is no standard measure of leverage. We follow G. Huang and Song (2006) and Memon et al. (2018) and measure leverage as the ratio of total debt (short term debt plus long term debt) to total debt plus book value of the equity. It is worth mentioning that we do not include all liabilities in our numerator. In fact, we include only the debt portion of the liabilities.

In order to ensure the robustness of our findings, we also calculate market leverage ratio by replacing the book value of equity with market value of equity in our leverage measure.

\subsection{Estimation Model}

Our explained variable leverage is a fractional variable whose value ranges from 0 to 1 . The conditional expectation for such variable is a non-linear function of independent variables (Cook et al., 2008), and some common specification errors might arise if a linear function is applied. Therefore, by following Papke and Wooldridge (1996) and Kieschnick and McCullough (2003), we use GLM with Logit Link function in order to find the association between corporate governance and firm leverage and the moderating role of firm age on this association. The description of all the variables used in this study is given in Appendix 1.

Due to the distinctive characteristics of atypical institutional structure of Chinese listed firms, we split our whole sample into two sub-samples of SOEs and NSOEs. We use the above mentioned GLM regression on each of our sub-samples in order to report our findings.

\section{Analysis, Results, and Discussion}

\subsection{Summary Statistics and Correlation Matrix}

Table 1 presents the summary statistics for NSOEs and SOEs in Panels A and B respectively. Average age of SOEs is higher (17.7 years) as compared to NSOEs (11.7 years) since the time of their listing. On average, 8 directors are serving on the NSOEs' board as compared to 10 directors on SOEs' board. Around $36 \%$ of the directors are independent in SOEs as well as NSOEs. Board of supervisors, on average, consists of 3 members for NSOEs and 4 members for SOES. The average number of commissions formed by the boards is around 4 for both NSOEs and SOEs. Mean leverage computed on the book value is 0.19 and 0.27 for NSOEs and SOEs, respectively. Mean leverage computed on market value is it is 0.37 and 0.98 for NSOEs and SOEs, respectively. This indicates that on average, SOEs are highly levered as compared to NSOEs, and Chinese markets consider SOEs as riskier than what is reported in the books.

Table 2 presents the pairwise correlation of all the variables used in this study. We find that both leverage and firm age are positively correlated with board size, number of independent directors and number of members on supervisory board. Leverage and firm age are negatively correlated with CEO duality and number of commissions established. The correlation between firm age and leverage is positive. Table 2 also suggests that there is no multicollinearity issue among the variables used in this study.

\subsection{Impact of Corporate Governance on Leverage and Moderating Role of Firm Age}

Columns (1) and (3) of Table 3 show the association between corporate governance and firm leverage using GLM regression for Chinese NSOEs (Panel A) and SOEs (Panel B), respectively. Board size exhibits a positive association with firm leverage, but this positive association is statistically insignificant in the case of NSOEs. This finding is in accordance with Anderson et al. (2004), who report that due to large number of directors on the board, the cost of debt declines, so such firms adopt a higher leverage policy in order to increase the value of the firm. The presence of independent directors on the board is negatively associated with firm leverage, but this negative relationship is not statistically significant in the case of NSOEs. The inverse relation between independent directors and leverage is consistent with Wen et al. (2002) who report that firms show lower tendency for debt when the governance structure is strong.

The relationship between supervisory board and leverage is similar to the relationship between board size and leverage, that is positive but insignificant for NSOEs. Firms with CEO duality show stronger inverse association than firms without CEO duality, however this inverse association is statistically insignificant for SOEs. This finding is similar to Kyereboah - coleman and Biekpe (2006) who also found an inverse association 
between CEO duality and firm leverage arguing that CEO duality increases the agency costs which discourages lenders from investing in such firms. Finally, we find a positive and statistically significant association between number of board commissions established and firm leverage in the case of NSOEs. Higher number of commissions established shows the presence of strong governance structure, so the lenders might find it more secure to invest in such firms.

Columns (2) and (4) of Table 3 show the GLM results for NSOEs and SOEs obtained after including the interaction terms of firm age with each governance measure. For NSOEs, we find that firm age only moderates the relationship between commissions established and leverage. In order to analyze further, we plot the graph to check the effect of different levels of firm age on the relationship between commissions established and leverage. We compute the low and high levels of firm age by computing the values of firm age at mean minus one standard deviation and mean plus one standard deviation, respectively. Figure 1 shows

Table 1. Descriptive statistics of the sample

\begin{tabular}{llllll}
\hline Variable & Obs & Mean & SD & Min & Max \\
\hline Panel A: NSOEs & & & & & \\
LV_BV & 14,074 & 0.1893 & 0.1855 & 0 & 0.7830 \\
LV_MV & 14,074 & 0.3740 & 0.0589 & 0.0536 & 0.9995 \\
Age_Establish & 14,074 & 18.2978 & 5.5498 & 2 & 32 \\
Age_Listing & 14,074 & 11.7625 & 6.6990 & 1 & 25 \\
BDir_SZ & 14,074 & 8.4331 & 1.5968 & 5 & 18 \\
I_Dir & 14,074 & 3.0949 & 0.5202 & 2 & 6 \\
BSup_SZ & 14,074 & 3.3300 & 0.8373 & 2 & 8 \\
dCEO & 14,074 & 0.3178 & 0.4656 & 0 & 1 \\
Comm & 14,074 & 3.7758 & 0.8320 & 0 & 8 \\
In_Lev & 14,074 & 0.3878 & 0.0975 & 0.0675 & 0.8080 \\
F_SZ & 14,074 & 21.3269 & 1.0297 & 14.1335 & 25.6591 \\
TGBL & 14,074 & 0.1152 & 0.1207 & 0.0000 & 0.9160 \\
PFTBL & 14,074 & 0.0803 & 0.3512 & -3.7358 & 38.2567 \\
P_PFTBL & 14,074 & 0.0691 & 0.2502 & -1.2628 & 0.4411 \\
Growth & 14,074 & -0.0525 & 0.3698 & -0.6998 & 3.2802 \\
& & & & & \\
Panel B: SOEs & & & & & \\
LV_BV & 12,850 & 0.2713 & 0.2163 & 0.0000 & 0.7830 \\
LV_MV & 12,850 & 0.9832 & 0.4163 & 0.0617 & 0.9995 \\
Age_Establish & 12,837 & 20.8966 & 4.2684 & 4 & 37 \\
Age_Listing & 12,850 & 17.7412 & 4.9214 & 1 & 27 \\
BDir_SZ & 12,850 & 9.5047 & 1.9725 & 5 & 19 \\
I_Dir & 12,850 & 3.3981 & 0.7461 & 2 & 8 \\
BSup_SZ & 12,850 & 4.2530 & 1.4203 & 2 & 8 \\
dCEO & 12,850 & 0.1884 & 0.2839 & 0 & 1 \\
Comm & 12,850 & 3.6141 & 1.1313 & 0 & 9 \\
In_Lev & 12,850 & 0.4360 & 0.0952 & 0.0438 & 0.7191 \\
F_SZ & 12,850 & 21.8922 & 1.3093 & 14.9375 & 28.2508 \\
TGBL & 12,850 & 0.1814 & 0.1813 & 0.0000 & 0.9598 \\
PFTBL & 12,850 & 0.0799 & 0.1530 & -0.8717 & 9.3502 \\
P_PFTBL & 12,850 & 0.0508 & 0.2230 & -1.2628 & 0.4411 \\
Growth & 12,850 & -0.1215 & 0.3260 & -0.6998 & 3.2802 \\
\hline & & & & &
\end{tabular}


Table 2. Correlation Matrix
(1)
(2)
(3)
(4)
(5)
(6)
(7)
(\$)
(9)
(10)
(11)
(12)
(13)

\begin{tabular}{|c|c|c|c|c|c|c|c|c|c|c|c|c|c|}
\hline LV_BV (1) & 1.000 & & & & & & & & & & & & \\
\hline Age_Listing (2) & 0.214 & 1.000 & & & & & & & & & & & \\
\hline BDir_SZ (3) & 0.152 & 0.168 & 1.000 & & & & & & & & & & \\
\hline I_Dir (4) & 0.127 & 0.102 & 0.266 & 1.000 & & & & & & & & & \\
\hline BSup_SZ(5) & 0.154 & 0.237 & 0.369 & 0.296 & 1.000 & & & & & & & & \\
\hline $\operatorname{dCEO}(6)$ & -0.107 & -0.257 & -0.180 & -0.114 & -0.165 & 1.000 & & & & & & & \\
\hline Comm (7) & -0.044 & -0.171 & -0.044 & 0.054 & -0.032 & 0.063 & 1.000 & & & & & & \\
\hline In_Lev (\$) & 0.301 & 0.352 & 0.131 & 0.125 & 0.179 & -0.150 & -0.043 & 1.000 & & & & & \\
\hline F_SZ (9) & 0.253 & 0.037 & 0.219 & 0.278 & 0.206 & -0.094 & 0.133 & 0.250 & 1.000 & & & & \\
\hline TGBL (10) & 0.214 & 0.032 & 0.166 & 0.100 & 0.197 & -0.077 & -0.121 & 0.031 & 0.001 & 1.000 & & & \\
\hline PFTBL (11) & -0.093 & 0.017 & 0.009 & 0.007 & 0.009 & -0.006 & 0.021 & 0.010 & 0.012 & -0.054 & 1.000 & & \\
\hline P_PFTBL (12) & -0.159 & -0.291 & 0.044 & 0.042 & 0.005 & 0.037 & 0.041 & -0.110 & 0.295 & 0.049 & 0.040 & 1.000 & \\
\hline Growth(13) & -0.044 & -0.150 & -0.038 & -0.028 & -0.055 & 0.073 & 0.009 & -0.103 & 0.011 & 0.084 & -0.039 & 0.073 & 1.000 \\
\hline
\end{tabular}

that the firm age negatively moderates this relationship. The positive association between commissions established and leverage is stronger at low levels of firm age $(B=0.0576, p<0.01)$ than at high levels of firm age $(\mathrm{B}=0.0349, \mathrm{p}<0.01)$. Our interpretation on this evidence is that young Chinese NSOEs with higher commissions established display stronger governance and might be able to convince lenders to invest in their firms. But when these firms grow older, they might prefer to choose more equity over debt. 
Table 3. Impact of corporate governance on leverage and moderating role of firm age

\begin{tabular}{|c|c|c|c|c|c|}
\hline \multirow[b]{2}{*}{ VARIABLES } & \multicolumn{2}{|c|}{ Panel A: NSOEs } & \multicolumn{3}{|c|}{ Panel B: SOEs } \\
\hline & (1) & (2) & (3) & (4) & \\
\hline \multirow[t]{2}{*}{ BDir_SZ } & 0.0247 & -0.0374 & $0.0435^{* * *}$ & 0.0587 & \\
\hline & $(0.0205)$ & $(0.0444)$ & $(0.0169)$ & $(0.0654)$ & \\
\hline \multirow[t]{2}{*}{ I_Dir } & -0.0333 & 0.161 & $-0.0720 * * *$ & $-0.376 * *$ & \\
\hline & $(0.0599)$ & $(0.139)$ & $(0.0451)$ & $(0.175)$ & \\
\hline \multirow[t]{2}{*}{ BSup_SZ } & -0.0151 & 0.0240 & $-0.00219 * *$ & $0.0294 * *$ & \\
\hline & & $(0.0262)$ & $(0.0690)$ & $(0.0152)$ & $(0.0558)$ \\
\hline \multirow[t]{2}{*}{$\mathrm{dCEO}$} & & $-0.0381 * *$ & $0.0670 * *$ & -0.000784 & 0.343 \\
\hline & & $(0.0505)$ & $(0.102)$ & $(0.0727)$ & $(0.269)$ \\
\hline \multirow[t]{2}{*}{ Comm } & & $0.0899 * * *$ & $0.0361 * *$ & 0.0154 & -0.0372 \\
\hline & & $(0.0253)$ & $(0.0902)$ & $(0.0187)$ & $(0.0976)$ \\
\hline \multirow[t]{2}{*}{ Age_Listing } & & $0.0182 * * *$ & $0.0535^{* * *}$ & $0.0123 * * *$ & $0.0539 * *$ \\
\hline & & $(0.00398)$ & $(0.0283)$ & $(0.00448)$ & $(0.0298)$ \\
\hline \multirow[t]{2}{*}{ Age_Listing*BDir_SZ } & & & 0.00455 & & -0.000759 \\
\hline & & & $(0.00295)$ & & $(0.00357)$ \\
\hline \multirow[t]{2}{*}{ Age_Listing*I_Dir } & & & -0.0140 & & $0.0168 * * *$ \\
\hline & & & $(0.00894)$ & & $(0.00940)$ \\
\hline \multirow[t]{2}{*}{ Age_Listing*BSup_SZ } & & & -0.000634 & & $0.00181 * * *$ \\
\hline & & & $(0.00407)$ & & $(0.00311)$ \\
\hline \multirow[t]{2}{*}{ Age_Listing*dCEO } & & & -0.00964 & & -0.0192 \\
\hline & & & $(0.00777)$ & & $(0.0146)$ \\
\hline \multirow[t]{2}{*}{ Age_Listing*Comm } & & & $-0.00671 * * *$ & & 0.00257 \\
\hline & & & $(0.00476)$ & & $(0.00496)$ \\
\hline \multirow[t]{2}{*}{ In_Lev } & & $1.743 * * *$ & $1.746^{* * *}$ & $2.553 * * *$ & $2.554 * * *$ \\
\hline & & $(0.252)$ & $(0.252)$ & $(0.227)$ & $(0.227)$ \\
\hline \multirow[t]{2}{*}{ F_SZ } & & $0.385 * * *$ & $0.389 * * *$ & $0.189 * * *$ & $0.194 * * *$ \\
\hline & & $(0.0237)$ & $(0.0237)$ & $(0.0178)$ & $(0.0180)$ \\
\hline \multirow[t]{2}{*}{ TGBL } & & $2.151 * * *$ & $2.163 * * *$ & $0.940 * * *$ & $0.940 * * *$ \\
\hline & & $(0.175)$ & $(0.175)$ & $(0.113)$ & $(0.113)$ \\
\hline \multirow[t]{2}{*}{ PFTBL } & & $-1.281 * * *$ & $-1.275 * * *$ & $-2.545 * * *$ & $-2.543 * * *$ \\
\hline & & $(0.206)$ & $(0.206)$ & $(0.233)$ & $(0.234)$ \\
\hline \multirow[t]{2}{*}{ PFTBL } & & $-0.692 * * *$ & $-0.699 * * *$ & $-0.989 * * *$ & $-1.008 * * *$ \\
\hline & & $(0.103)$ & $(0.103)$ & (0.0994) & $(0.0997)$ \\
\hline \multirow[t]{2}{*}{ Growth } & & $-0.222 * * *$ & $-0.220 * * *$ & 0.0238 & 0.0207 \\
\hline & & $(0.0651)$ & $(0.0652)$ & $(0.0646)$ & $(0.0648)$ \\
\hline \multirow[t]{2}{*}{ Constant } & & $-10.58 * * *$ & $-11.29 * * *$ & $-6.667 * * *$ & $-5.564 * * *$ \\
\hline & & $(0.489)$ & $(0.680)$ & $(0.383)$ & $(0.652)$ \\
\hline Observations & & 14,074 & 14,074 & 12,850 & 12,850 \\
\hline
\end{tabular}

$* * *=\mathrm{p}<0.01, * *=\mathrm{p}<0.05 \& *=\mathrm{p}<0.10$. Values in parentheses represent standard errors. 
Figure 1: Effect of Age_Listing on the association between Comm \& LV_BV

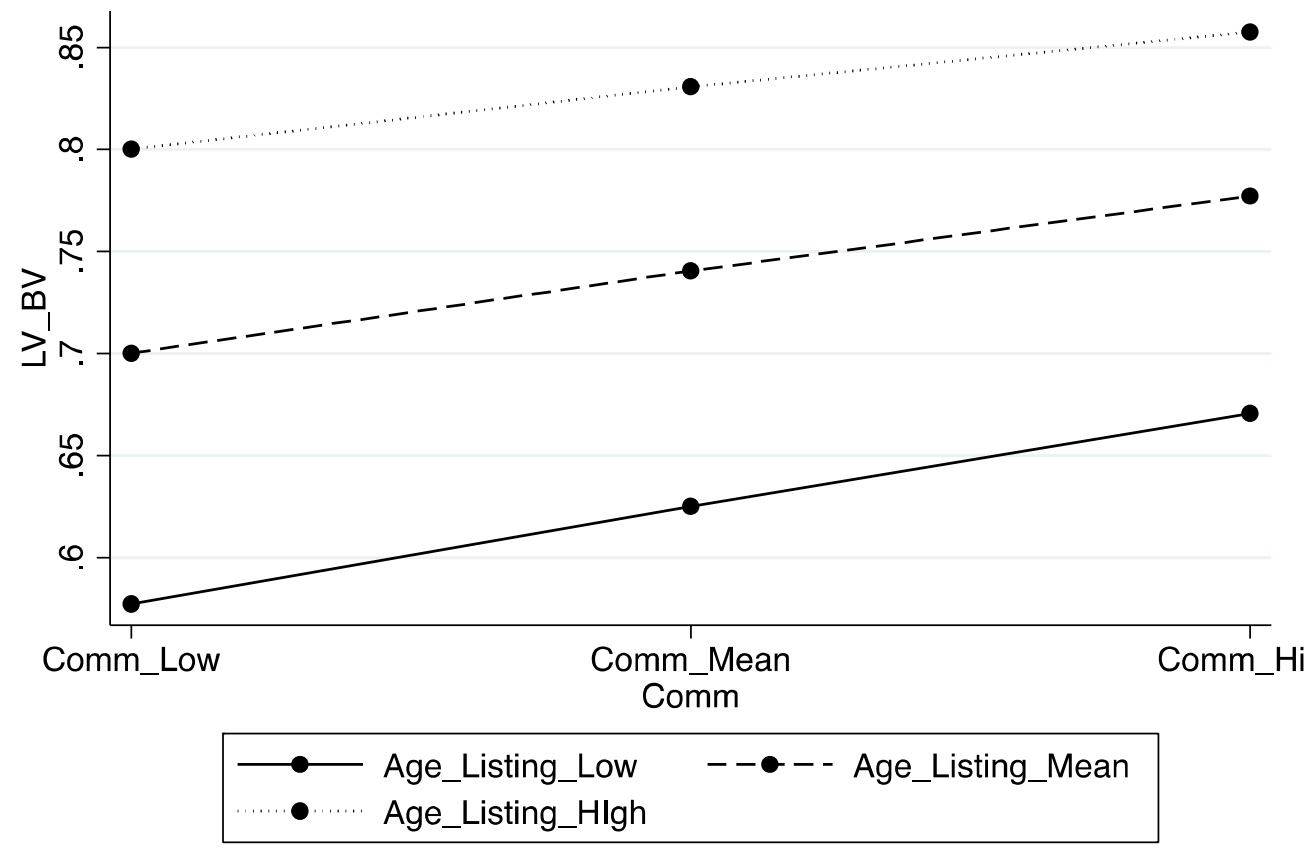

Figure 2: Effect of Age_Listing on the association between I_Dir \& LV_BV

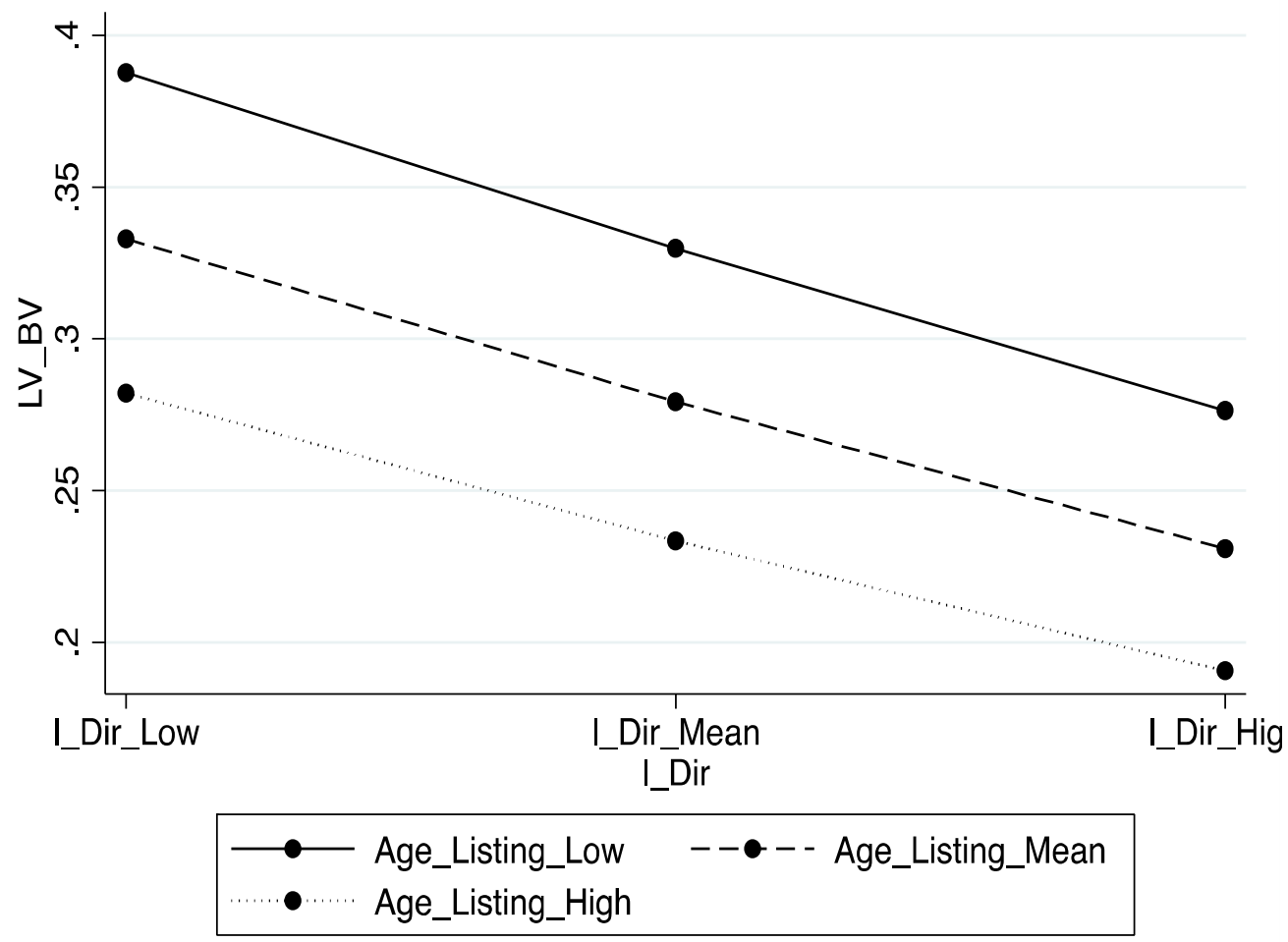


Figure 3: Effect of Age_Listing on the association between BSup_SZ \& LV_BV

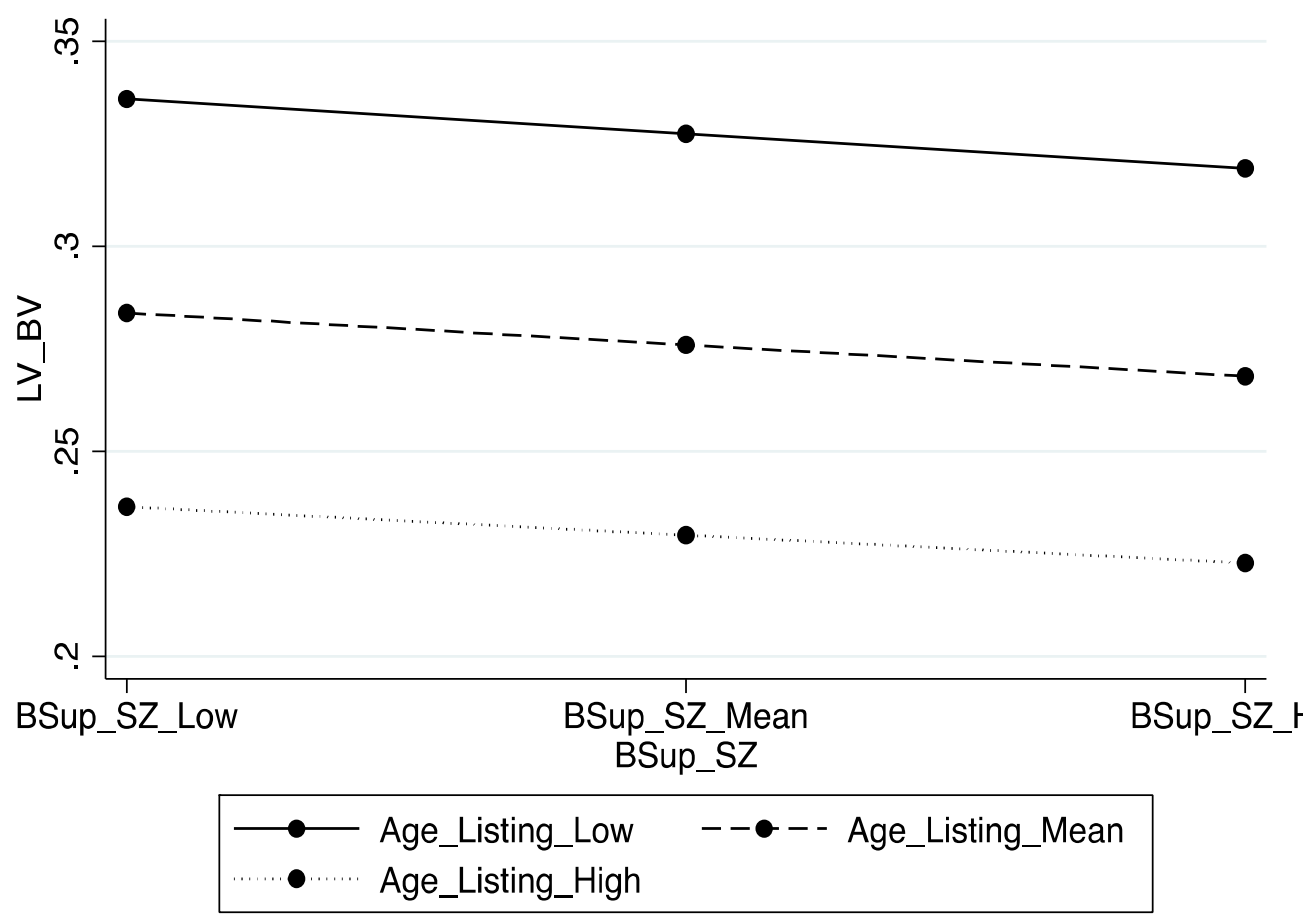

For SOEs, we find that the interactions terms of firm age with board independence and supervisory board are statistically significant. Figure 2 shows the effect of different levels of firm age on the association between board independence and leverage. The negative relationship between board independence on leverage becomes weaker as the firm ages $(B=-0.0764, p=<001$ at low levels of firm age; $B=-.0620, p<0.01$ at high levels of firm age). Figure 3 shows that firm age positively moderates the association between supervisory board and leverage. The negative association between supervisory board and leverage is stronger at low levels of firm age $(B=-$ $0.0060, \mathrm{p}<0.01)$ than at high levels of firm age $(\mathrm{B}=-.00444, \mathrm{p}<0.01)$. Thus, we find that firm age positively moderates the negative effects of governance measures on leverage. The reason behind this might be that the costs of debt for aging Chinese SOEs decrease which enables them to obtain more debt.

\section{Robustness}

\subsection{Alternative Measure of Leverage}

We test the robustness of our findings reported earlier by using another measure of the explained variable leverage (LV_MV), computed as the ratio of total debt divided by total debt plus market value of equity and report our findings in Table 4. We include the control variables in our regression model, but we do not report coefficients of those variables in Table 4 for the sake of conciseness. We find that CEO duality in NSOEs has a negative effect on leverage, while commission established has a positive effect on leverage. Firm age does not significantly affect the relationship between CEO duality on leverage, however, it negatively moderates the positive association between number of commissions established and leverage. In short, NSOEs initially with large number of commissions established use more leverage, but firm aging reduces the intensity of this positive association. For SOEs, firms with large number of independent directors initially opt less leverage, but aging enables them to use high leverage. Similarly, the effect of supervisory boards on leverage level is negative, but as the firm ages, the strength of negative relationship declines. Overall, we find that these results remain consistent to our main results as reported in Table 3 even after using an alternative measure for leverage. 
Table 4. Moderating effect of firm age using alternative leverage measure

\begin{tabular}{|c|c|c|c|c|}
\hline \multirow[b]{2}{*}{ VARIABLES } & \multicolumn{2}{|c|}{ Panel A: NSOEs } & \multicolumn{2}{|c|}{ Panel B: SOEs } \\
\hline & (1) & (2) & (1) & (2) \\
\hline \multirow[t]{2}{*}{ BDir_SZ } & 0.0457 & 0.0311 & $0.0821 * * *$ & $0.0167 *$ \\
\hline & $(0.0196)$ & $(0.0387)$ & $(0.0222)$ & $(0.0819)$ \\
\hline \multirow[t]{2}{*}{ I_Dir } & 0.0160 & 0.0329 & $-0.00286^{* *}$ & $-0.357 * *$ \\
\hline & $(0.0605)$ & $(0.130)$ & $(0.0581)$ & $(0.214)$ \\
\hline \multirow[t]{2}{*}{ BSup_SZ } & 0.0538 & 0.00686 & $-0.0128 * * *$ & $0.166 * *$ \\
\hline & $(0.0308)$ & $(0.0750)$ & $(0.0202)$ & $(0.0684)$ \\
\hline \multirow[t]{2}{*}{$\mathrm{dCEO}$} & $-0.0922 * * *$ & $0.160 * *$ & 0.0271 & 0.0507 \\
\hline & $(0.0458)$ & $(0.0866)$ & $(0.0884)$ & $(0.299)$ \\
\hline \multirow[t]{2}{*}{ Comm } & $0.206 * * *$ & $0.314 * * *$ & -0.0181 & -0.0651 \\
\hline & $(0.0290)$ & $(0.0848)$ & $(0.0240)$ & $(0.118)$ \\
\hline \multirow[t]{2}{*}{ Age_Listing } & $0.0114 * * *$ & $0.102 * * *$ & $0.0160 * * *$ & -0.0571 \\
\hline & $(0.00395)$ & $(0.0301)$ & $(0.00519)$ & $(0.0375)$ \\
\hline \multirow[t]{2}{*}{ Age_Listing*BDir_SZ } & & 0.000948 & & 0.00386 \\
\hline & & $(0.00287)$ & & $(0.00452)$ \\
\hline \multirow[t]{2}{*}{ Age_Listing*I_Dir } & & -0.00149 & & $0.0198 * *$ \\
\hline & & $(0.00916)$ & & $(0.0117)$ \\
\hline \multirow[t]{2}{*}{ Age_Listing*BSup_SZ } & & 0.00312 & & $-0.00913 * *$ \\
\hline & & $(0.00470)$ & & $(0.00385)$ \\
\hline \multirow[t]{2}{*}{ Age_Listing*dCEO } & & -0.0248 & & -0.00154 \\
\hline & & $(0.00712)$ & & $(0.0165)$ \\
\hline \multirow[t]{2}{*}{ Age_Listing*Comm } & & $-0.0310 * * *$ & & 0.00236 \\
\hline & & $(0.00491)$ & & $(0.00602)$ \\
\hline Control Variables & Yes & Yes & Yes & Yes \\
\hline \multirow[t]{2}{*}{ Constant } & $-15.90 * * *$ & $-17.98 * * *$ & $-9.991 * * *$ & $-8.757 * * *$ \\
\hline & $(0.566)$ & $(0.730)$ & $(0.562)$ & $(0.863)$ \\
\hline Observations & 14,074 & 14,074 & 12,850 & 12,850 \\
\hline
\end{tabular}

4.2 Alternative Measure of Firm Age

Our primary measure of firm age is the number of years since the firm got listed. But we also generate the results using an alternative measure of firm age computed as the number of years since the firm got established. Table 5 displays these results. We find that these results are similar to our main results reported in Table 3 , except slight changes in the statistical significance level of some coefficients. We find that the interaction term of firm age and number of commissions established is negative and statistically significant for NSOEs, Whereas, for SOEs, we find that interaction terms of firm age with board independence and supervisory board are positive and statistically significant. Hence, our overall findings remain unaffected after using a different measure of firm age, which confirms the robustness of our findings. 
Table 5. Moderating effect of firm age using an alternative measure of firm age.

\begin{tabular}{|c|c|c|c|c|}
\hline \multirow[b]{2}{*}{ VARIABLES } & \multicolumn{2}{|c|}{ Panel A: NSOEs } & \multicolumn{2}{|c|}{ Panel B: SOEs } \\
\hline & (1) & (2) & (3) & (4) \\
\hline \multirow{2}{*}{ BDir_SZ } & 0.0262 & -0.0623 & $0.0405^{* *}$ & 0.0103 \\
\hline & $(0.0205)$ & $(0.0713)$ & $(0.0170)$ & $(0.0778)$ \\
\hline \multirow[t]{2}{*}{ I_Dir } & -0.0327 & 0.306 & $-0.0623 *$ & $-0.433 * *$ \\
\hline & $(0.0600)$ & $(0.214)$ & $(0.0453)$ & $(0.201)$ \\
\hline \multirow[t]{2}{*}{ BSup_SZ } & 0.0285 & -0.0446 & $-0.0204 * * *$ & $-0.173 *$ \\
\hline & $(0.0260)$ & $(0.100)$ & $(0.0153)$ & $(0.0773)$ \\
\hline \multirow[t]{2}{*}{$\mathrm{dCEO}$} & $-0.0597 * *$ & $0.0559 * * *$ & -0.00616 & 0.459 \\
\hline & $(0.0501)$ & $(0.170)$ & $(0.0727)$ & $(0.364)$ \\
\hline \multirow[t]{2}{*}{ Comm } & $0.104 * * *$ & $0.119 * * *$ & 0.0150 & -0.0167 \\
\hline & $(0.0251)$ & $(0.119)$ & $(0.0187)$ & $(0.108)$ \\
\hline \multirow[t]{2}{*}{ Age_Establish } & $0.0106^{* *}$ & 0.0536 & $0.0215 * * *$ & $0.0917 * * *$ \\
\hline & $(0.00438)$ & $(0.0327)$ & $(0.00499)$ & $(0.0315)$ \\
\hline \multirow[t]{2}{*}{ Age_Establish*BDir_SZ } & & 0.00462 & & 0.00140 \\
\hline & & $(0.00357)$ & & $(0.00371)$ \\
\hline \multirow[t]{2}{*}{ Age_Establish*I_Dir } & & -0.0175 & & $0.0176^{*}$ \\
\hline & & $(0.0106)$ & & $(0.00949)$ \\
\hline \multirow[t]{2}{*}{ Age_Establish*BSup_SZ } & & 0.00352 & & $0.00855 * *$ \\
\hline & & $(0.00468)$ & & $(0.00371)$ \\
\hline \multirow[t]{2}{*}{ Age_Establish*dCEO } & & -0.00662 & & -0.0223 \\
\hline & & $(0.00897)$ & & $(0.0169)$ \\
\hline \multirow[t]{2}{*}{ Age_Establish*Comm } & & $-0.00995 * * *$ & & 0.00133 \\
\hline & & $(0.00520)$ & & $(0.00485)$ \\
\hline Control Variables & Yes & Yes & Yes & Yes \\
\hline \multirow[t]{2}{*}{ Constant } & $-10.72 * * *$ & $-11.72 * * *$ & $-6.960 * * *$ & $-4.702 * * *$ \\
\hline & $(0.496)$ & $(0.849)$ & $(0.392)$ & $(0.754)$ \\
\hline Observations & 14,074 & 14,074 & 12,837 & 12,837 \\
\hline
\end{tabular}

$* * *=\mathrm{p}<0.01, * *=\mathrm{p}<0.05 \& *=\mathrm{p}<0.10$. Values in parentheses represent standard errors.

\subsection{Endogeneity}

Investigating the effect of corporate governance on firm leverage might give rise to different endogeneity concerns as identified by many previous studies (Kieschnick \& Moussawi, 2018). In order to deal with potential endogeneity problems, we lag all our independent variables by one year. Using the lag of independent variables in our regression model generates unbiased and reliable estimates. The regression results after using lagged variables, as displayed in Table 6, remain consistent with our main results that we presented in Table 3 . It indicates that our main estimates are not biased due to any endogeneity issues. 
Table 6. Moderating effect of firm age using lag of all explanatory variables

\begin{tabular}{|c|c|c|c|c|}
\hline \multirow[b]{2}{*}{ VARIABLES } & \multicolumn{2}{|c|}{ Panel A: NSOEs } & \multicolumn{2}{|c|}{ Panel B: SOEs } \\
\hline & (1) & (2) & (3) & (4) \\
\hline \multirow[t]{2}{*}{ BDir_SZ } & 0.0347 & -0.0172 & $0.0459 * * *$ & 0.0668 \\
\hline & $(0.0213)$ & $(0.0488)$ & $(0.0178)$ & $(0.0691)$ \\
\hline \multirow[t]{2}{*}{ I_Dir } & -0.0253 & 0.153 & $-0.0649 * *$ & $-0.392 * * *$ \\
\hline & $(0.0615)$ & $(0.150)$ & $(0.0471)$ & $(0.185)$ \\
\hline \multirow[t]{2}{*}{ BSup_SZ } & 0.0110 & 0.0259 & $-0.00417 *$ & $-0.0244 * *$ \\
\hline & $(0.0272)$ & $(0.0732)$ & $(0.0157)$ & $(0.0586)$ \\
\hline \multirow[t]{2}{*}{$\mathrm{dCEO}$} & $-0.0176 * * *$ & $0.0769 * * *$ & -0.0152 & 0.374 \\
\hline & $(0.0538)$ & $(0.112)$ & $(0.0759)$ & $(0.285)$ \\
\hline \multirow[t]{2}{*}{ Comm } & $0.0893 * * *$ & $0.0223 *$ & 0.00788 & -0.0802 \\
\hline & $(0.0253)$ & $(0.0942)$ & $(0.0190)$ & $(0.0999)$ \\
\hline \multirow[t]{2}{*}{ Age_Listing } & $0.0165 * * *$ & $0.0515^{*}$ & $0.00907^{*}$ & $0.0641 * *$ \\
\hline & $(0.00428)$ & $(0.0301)$ & $(0.00475)$ & $(0.0311)$ \\
\hline \multirow[t]{2}{*}{ Age_Listing*BDir_SZ } & & 0.00368 & & -0.00106 \\
\hline & & $(0.00315)$ & & $(0.00377)$ \\
\hline \multirow[t]{2}{*}{ Age_Listing*I_Dir } & & -0.0124 & & $0.0179 *$ \\
\hline & & $(0.00948)$ & & $(0.00990)$ \\
\hline \multirow[t]{2}{*}{ Age_Listing*BSup_SZ } & & -0.000965 & & $0.00163 * *$ \\
\hline & & $(0.00432)$ & & $(0.00327)$ \\
\hline \multirow[t]{2}{*}{ Age_Listing*dCEO } & & -0.00848 & & -0.0217 \\
\hline & & $(0.00848)$ & & $(0.0155)$ \\
\hline \multirow[t]{2}{*}{ Age_Listing*Comm } & & $-0.00589^{*}$ & & 0.00441 \\
\hline & & $(0.00494)$ & & $(0.00509)$ \\
\hline Control Variables & Yes & Yes & Yes & Yes \\
\hline \multirow[t]{2}{*}{ Constant } & $-10.39 * * *$ & $-11.07 * * *$ & $-6.430 * * *$ & $-5.197 * * *$ \\
\hline & $(0.526)$ & $(0.728)$ & $(0.401)$ & $(0.680)$ \\
\hline Observations & 12,258 & 12,258 & 11,698 & 11,698 \\
\hline
\end{tabular}

\section{Conclusion}

Optimal leverage and strong corporate governance structures are vital for increasing the value of the firm and maximizing the wealth of shareholders. However, prior literature suggests that the governance characteristics and leverage structures change at various life cycles of the firm. Therefore, in this study we endeavor to establish the influence of corporate governance on firm leverage. We also find how various levels of firm age affect the association between corporate governance and leverage.

Keeping in mind various errors in previous studies related to leverage, we undertake some measures in order to generate reliable empirical findings. To do so, we compute leverage as the ratio of debt-to-equity rather than debt-to-assets, because equity is a converse of debt (Welch, 2007). Furthermore, leverage is a ratio whose value ranges 0 to 1 , and using a linear regression model might not be appropriate, we therefore use GLM with logit link function to find the relationship between corporate governance and leverage.

Using a sample of Chinese listed firms from 2003 to 2017, we present findings separately for SOEs and NSOEs as both have different governance and leverage characteristics. We provide evidence that commissions established by the board have positive effect on leverage of NSOEs, however this positive relationship becomes less strong as the firm ages. The reason might be the less preference for debt by aging NSOEs. While for SOEs, board independence and supervisory board are found to have negative effect on leverage, however this negative relationship is less strong as the firm ages. The reason for this might be the lower costs of debt when an SOE grows older.

We use several sensitivity checks to confirm the robustness of our findings. After using an alternative measure of leverage on market value basis and an alternative measure of firm age based on the time since the establishment of the firm, we find that our main results remain qualitatively unchanged. Additionally, in order to avoid any possible endogeneity concerns as identified by the prior literature, we lag all our explanatory variables by one year. We then run the regression again, and find that the estimates generated are similar to our main estimates, suggesting that our main estimates are not affected by any endogeneity concerns. 


\begin{tabular}{lll} 
Appendix. 1 & & \\
\hline Abbreviation & Description & Measurement \\
\hline LV_BV & Book value leverage & Total debt/(Total debt + book value of equity) \\
\hline LV_MV & Market value leverage & Total debt/(Total debt + market value of equity) \\
\hline Age_Establish & Firm age since establishment & 2017-Establishment Year \\
\hline Age_Listing & Firm age since the listing date & 2017-Listing Year \\
\hline BDir_SZ & Board Size & Number of directors on the board \\
\hline I_Dir & Board Independence & Number of independent directors on the board \\
\hline BSup_SZ & Supervisory board & Number of members on the supervisory board \\
\hline dCEO & CEO duality & A dummy variable: 1 representing that CEO and Chairman \\
& & are the same persons; 0 otherwise \\
\hline Comm & Board Commissions & Number of commissions established under the board in a year \\
\hline In_Lev & Industry Leverage & Median of LV_BV for each industry in a year \\
\hline F_SZ & Firm Size & Natural logarithm of total assets \\
\hline TGBL & Tangibility & Fixed assets / total assets \\
\hline PFTBL & Profitability & Earnings before interest and tax / total assets \\
\hline P_PFTBL & Past Profitability & Retained earnings / total assets \\
\hline Growth & Growth & Year-on-year percentage change in total assets \\
\hline
\end{tabular}

\section{References}

Ahmed Sheikh, N., \& Wang, Z. (2012). "Effects of corporate governance on capital structure: empirical evidence from Pakistan”. Corporate Governance: The international journal of business in society, 12(5), 629-641.

Anderson, R. C., Mansi, S. A., \& Reeb, D. M. (2004). "Board characteristics, accounting report integrity, and the cost of debt". Journal of accounting and economics, 37(3), 315-342.

Bacon, J., \& Brown, J. (1973). "Corporate directorship practices: Roles, selection, and legal status of the board. New York: The Conference Board".

Bai, C.-E., Liu, Q., Lu, J., Song, F. M., \& Zhang, J. (2004). "Corporate governance and market valuation in China". Journal of comparative economics, 32(4), 599-616.

Black, B. (2000). "Does Corporate Governance Matter--A Crude Test Using Russian Data". University of Pennsylvania Law Review, 149, 2131.

Cheng, S. (2008). "Board size and the variability of corporate performance". Journal of financial economics, 87(1), 157-176.

Cook, D. O., Kieschnick, R., \& McCullough, B. D. (2008). "Regression analysis of proportions in finance with self selection”. Journal of empirical finance, 15(5), 860-867.

Daily, C. M., \& Dalton, D. R. (1994). "Corporate governance and the bankrupt firm: An empirical assessment". Strategic Management Journal, 15(8), 643-654.

Filatotchev, I., Toms, S., \& Wright, M. (2006). "The firm's strategic dynamics and corporate governance lifecycle". International Journal of Managerial Finance, 2(4), 256-279.

Gompers, P., Ishii, J., \& Metrick, A. (2003). "Corporate governance and equity prices". The quarterly journal of economics, 118(1), 107-156.

Hovakimian, A., Opler, T., \& Titman, S. (2001). "The debt-equity choice". Journal of Financial and Quantitative analysis, 36(1), 1-24.

Huang, G., \& Song, F. M. (2006). "The Determinants of Capital Structure: Evidence from China". China economic review, 17(1), 14-36.

Huang, Y. S., \& Wang, C.-J. (2015). "Corporate governance and risk-taking of Chinese firms: The role of board size". International Review of Economics \& Finance, 37, 96-113.

Jensen, M. C. (1993). "The modern industrial revolution, exit, and the failure of internal control systems". The journal of finance, 48(3), 831-880.

Johnson, W. C., Karpoff, J. M., \& Yi, S. (2016). "The lifecycle of firm takeover defenses". University of Washington Foster School of Business Working Paper.

Kieschnick, R., \& McCullough, B. D. (2003). "Regression analysis of variates observed on (0, 1): percentages, proportions and fractions". Statistical modelling, 3(3), 193-213.

Kieschnick, R., \& Moussawi, R. (2018). "Firm age, corporate governance, and capital structure choices". Journal of Corporate Finance, 48, 597-614.

Kyereboah - coleman, A., \& Biekpe, N. (2006). "Corporate governance and financing choices of firms: A panel data analysis". South African Journal of Economics, 74(4), 670-681.

Liu, H., \& Fong, M. W. (2010). "Board characteristics of medium and large Chinese companies". Corporate 
Governance: The international journal of business in society, 10(2), 163-175.

Memon, Z. A., Chen, Y., Tauni, M. Z., \& Ali, H. (2018). "The impact of cash flow volatility on firm leverage and debt maturity structure: evidence from China”. China Finance Review International, 8(1), 69-91.

Obradovich, J., \& Gill, A. (2012). "The impact of corporate governance and financial leverage on the value of American firms". International Research Journal of Finance and Economics(Issue 91).

Oliver, C. (2004). "The mighty meeting". Board Leadership, 2004(75), 1-8.

Papke, L. E., \& Wooldridge, J. M. (1996). "Econometric methods for fractional response variables with an application to 401 (k) plan participation rates". Journal of applied econometrics, 11(6), 619-632.

Rouf, A. (2014). "The Relationship between Corporate Governance and Value of the Firm in Developing Countries: Evidence from Bangladesh". Journal of Economics and Business Research, 18(1), 73-85.

Shleifer, A., \& Vishny, R. W. (1997). “A survey of corporate governance”. The journal of finance, 52(2), 737783.

Sundaresan, S., Wang, N., \& Yang, J. (2015). "Dynamic investment, capital structure, and debt overhang". The Review of Corporate Finance Studies, 4(1), 1-42.

Wei, G. (2007). "Ownership structure, corporate governance and company performance in China". Asia Pacific Business Review, 13(4), 519-545.

Welch, I. (2007). Common flaws in empirical capital structure research. Paper presented at the AFA 2008 New Orleans Meetings Paper.

Wen, Y., Rwegasira, K., \& Bilderbeek, J. (2002). "Corporate governance and capital structure decisions of the Chinese listed firms". Corporate Governance: An International Review, 10(2), 75-83.

Wu, S. K., Liu, Z. M., \& Fan, J. Q. (2001). "Empirical analysis on non-executive directors and corporate performance". Chinese Industrial Economy, 9, 69-76.

$\mathrm{Xu}, \mathrm{X} .$, \& Wang, Y. (1997). Ownership structure, corporate governance, and corporate performance: The case of Chinese stock companies (Vol. 1794): World Bank Publications. 